\title{
Effect of Planting Density and Nutrient Management Practices on the Performance of Maize Hybrids during kharif Season
}

\author{
Pramila Naik, Ashutosh Nanda*, Digvijay Swain, \\ Kalpataru Nanda and Rutuparna Paikaray
}

${ }^{1}$ AICRP on Maize improvement scheme, ${ }^{2}$ Forecasting Agricultural Output using Space, Agrometeorology and Land based observations scheme, ${ }^{3}$ NRRI, Cuttack, ${ }^{4}$ Krishi Vigyan Kendra, Angul, Odisha University of Agriculture \& Technology, Bhubaneswar, Odisha, India

*Corresponding author

\section{Keywords}

Maize, plant geometry, Soil Test Crop Response (STCR), SiteSpecific Nutrient Management (SSNM), RDF

\section{Article Info}

Accepted: 07 January 2021 Available Online: 10 February 2021
Field experiments were carried out to study the effect of planting density and nutrient management practices on the performance of maize hybrids in acidic soils of Odisha in the coastal ecosystem in kharif season during 2015, 2016 and 2017. The experiment was laid out in a split-split plot design with three replications, using two hybrids (Hishel and P3441) allotted to the main-plots, two planting density to the sub-plots and three nutrient management practices to the sub- sub-plots. The Hybrid P3441 influenced higher growth parameters, more plant population (86.7thousand /ha), produced maximum cob yield (7122 $\mathrm{kg} / \mathrm{ha}-11.1 \%)$, grain yield $(6202 \mathrm{~kg} / \mathrm{ha}-7.9 \%)$ and stover yield (17791 kg/ha-14.4\%) to Hishel (6413 kg/ha, $5739 \mathrm{~kg} / \mathrm{ha}, 15550 \mathrm{~kg} / \mathrm{ha})$ respectively. Similarly, the high plant geometry $(50 \mathrm{~cm} \times 20 \mathrm{~cm})$ significantly yielded highest cob yield $(7497 \mathrm{~kg} / \mathrm{ha}-18.5 \%)$, grain yield $(6122 \mathrm{~kg} / \mathrm{ha}-7.7 \%)$ and stover yield $(17783 \mathrm{~kg} / \mathrm{ha}-14.3 \%)$ as compared to normal plant geometry $(60 \mathrm{~cm} \times 20 \mathrm{~cm})$ i.e. $6327 \mathrm{~kg} / \mathrm{ha}, 5684 \mathrm{~kg} / \mathrm{ha}$ and $15557 \mathrm{~kg} / \mathrm{ha}$, respectively. Likewise, among the three nutrient management practices, Soil Test Crop Response (STCR) significantly resulted in highest cob yield $(7564 \mathrm{~kg} / \mathrm{ha})$, grain yield $(6328 \mathrm{~kg} / \mathrm{ha})$ and stover yield (17786 kg/ha) over RDF (6219 kg/ha, $5310 \mathrm{~kg} / \mathrm{ha}$ and $14792 \mathrm{~kg} / \mathrm{ha})$, but it remained at par with Site-Specific Nutrient Management (SSNM) $7237 \mathrm{~kg} \mathrm{cob} / \mathrm{ha}, 6074$ $\mathrm{kg}$ grain /ha and $17228 \mathrm{~kg}$ stover /ha. The increase in cob yield, grain yield and stover yield of STCR was $21.6 \%, 19.2 \%$ and $20.2 \%$ higher over RDF and $16.3 \%, 14.4 \%$ and $16.5 \%$ to SSNM. The hybrid P3441 influenced maximum net return of Rs.55488/ha (18.0\%) higher with $\mathrm{B}: \mathrm{C}$ ratio of 1.40 as compared to hybrid Hishel [net return Rs 47041/ha, B:C (1.22)]. Similarly, the high plant geometry $(50 \mathrm{~cm}$ x $20 \mathrm{~cm})$ significantly found highest net return of Rs.55368 of $17.4 \%$ more with B:C ratio of 1.41 over normal plant geometry $(60 \mathrm{~cm} x 20 \mathrm{~cm})$ i. e. net return of Rs.47161/ha with B:C ratio of 1.34 . Likewise, Soil Test Crop Response (STCR) practice significantly increased maximum net return of Rs.57921/ha with $38.8 \%$ higher with $\mathrm{B}: \mathrm{C}$ ratio of 1.46 over $\mathrm{RDF}$ (net return Rs.41741/ha with B:C 1.11) and SSNM (net return of Rs.54141/ha with B:C ratio of 1.38). 


\section{Introduction}

Maize is one of the most versatile crop, has the highest genetic yield potential and known as queen of cereals in the world. Since the inception of Green Revolution there has been a race for increasing food grain (mainly cereals) production using chemical fertilizers in India. However, cereal production in the country increased only five fold, while fertilizer consumption increased 322 times during the 1950-51 to 2007-08 periods, implying very low fertilizer use efficiency. During 2015-16, maize was cultivated over an area 8.69 million ha with 21.81 million tonnes production having an average productivity of $2509 \mathrm{~kg} / \mathrm{ha}$ (ICAR-IIMR 2016). General fertilizer recommendation and current farmers' fertilizer practice are not based on the nutrient requirements of the maize crop and the nutrients available in the soil. The yield potential of maize can only be realized when it is grown with adequate fertilization and optimum plant population (Singh and Singh, 2006). Due to higher nutrient demand and different plant type the hybrid needs modification in production technology especially for nutrient and plant geometry. So, to achieve higher productivity and resourceuse efficiency optimum plant stand is an important factor. Plant density affects growth and developmental patterns, influences carbohydrate production and partition and ultimately the yield of the crop. Maize is more sensitive to variations in plant density than other members of the grass family. Therefore, it is necessary to identify optimum planting densities to facilitate efficient utilization and transformation of the available growth resources into grain production in maize.

Fertilizer is one of the most important agriculture inputs for increasing the crop production. The fertilizer application by the farmers in the field without knowledge of soil fertility status and nutrient requirement of different crops usually leads to adverse effect on soil as well as crops by way of nutrient deficiency or toxicity due to overuse or inadequate use of fertilizers. In regard, targeted yield approach has been found to be beneficial which recommends balanced fertilization considering available nutrient status, in the soil and the crop needs. Nutrient requirement of maize, varies from field to field due to high variability in soil fertility across farmer's fields and also varies with the yield potential of hybrids. Therefore, single homogenous nutrient recommendations may not be very useful for improving maize yield. To overcome this problem adoption of the emerging concept of precision agriculture wherein, the input variables such as fertilizers are applied in the right amount, at the right place and at the time (variable rate application) as per the demand of the crop. It helps to improve input-use-efficiency, economic and ensure sustainable use of natural resources, as it is minimizes wastage. Site-Specific Nutrient Management (SSNM) approach is one such option which focuses on balanced and crop need-based nutrient approach (Johnston et al., 2014). SSNM ensures balanced and precise nutrition application of nitrogen, phosphorus and potassium along with secondary micronutrients based on the nutrient supplying capacity of the soil and nutrient requirement of a particular crop to produce a unit quantity of yield or set yield target.

The maize crop in kharif season requires comparatively less input as compare to most competing paddy crop of the season where farmers are harvesting double yield of maize than rice. The plant geometry and optimum plant population play an important role in plant growth, yield attributing characters and yield of crop. At present there is lack of nutrient recommendation according to area based climatic situation as well as nutrient status of soil. There is wide gap between 
nutrient addition and nutrient removal. This is one of the major reasons for lower production at farmer's field. Without knowing soil fertility status and nutrient requirement of maize hybrids it is not possible to harvest potential yield. Keeping this view in mind, an experiment was undertaken to study the effect of hybrid, plant geometry and levels of nutrients on growth and yield of kharif maize.

\section{Materials and Methods}

The Field experiments were carried out during 2014, 2015 and 2016 at the Central Research Station, Orissa University of Agriculture and Technology, Bhubaneswar $\left(20^{\circ} 26^{\prime} \mathrm{N}, 85^{\circ} 81^{\prime} \mathrm{E}, 25.9 \mathrm{~m}\right.$ above mean sea level and about $64 \mathrm{~km}$ away of the Bay of Bengal), Odisha under the aegis of AICRP on Maize to find out the soil test crop response through fertilizer prescription equations assisted SSNM and RDF practices for achieving targeted yield of hybrid maize under precision agriculture. The station comes under the East and South Eastern Coastal Plain Agro-climatic Zone of Odisha and covered under Hot Sub-humid Semi-arid Ecoregion with Coastal Alluvium (18-S-7CD2-5) Agro Ecological Region of the country. The place is characterized by warm and moist climate with hot and humid summer and mild winter. The average annual rainfall is 1502 $\mathrm{mm}$ of which more than $80 \%$ is generally received during the monsoon season (June October). The average rainfall received during the crop growing period of experiment from July to October was $845.2 \mathrm{~mm}$. The soil of the experimental field was loamy sand in texture, slightly acidic in reaction, low in Organic carbon $(0.41 \%)$ and available nitrogen $(216 \mathrm{~kg} / \mathrm{ha})$, medium in available phosphorus (27 kg/ha) and high in available potassium (342 kg/ha). The experiment was laid out in a split-split plot design. The two hybrids were Hishel and P3441, three nutrient management practices were SSNM
(140:41:77 $\left.\mathrm{N}: \mathrm{P}_{2} \mathrm{O}_{5}: \mathrm{K}_{2} \mathrm{O} \mathrm{kg} / \mathrm{ha}\right)$ based on target yield (65. $0 \mathrm{q} / \mathrm{ha})$, STCR (143:15:78) $\left.\mathrm{N}: \mathrm{P}_{2} \mathrm{O}_{5}: \mathrm{K}_{2} \mathrm{O} \mathrm{kg} / \mathrm{ha}\right)$ through fertilizer prescription equation target yield $(65.0 \mathrm{q} / \mathrm{ha})$ and RDF (120:60:60 kg N-P-K/ha). The crop was sown in the month of July during kharif 2014, 2015 and 2016. One third of Nitrogen and full dose of Phosphorous and potassium were applied as basal dose at the time of sowing as urea, single superphosphate and muriate of potash and the remaining $2 / 3$ dose of nitrogen was applied as top dressing in two equal splits, first top dressing at the time of knee high stage and second top dressing at the time of tasseling stage of the crop. The Intercultural operations, irrigation and weed control measures were adopted whenever is necessary. Intercultural operations were also done two times during the crop season. The growth parameters were measured at the time of maturity stage and the yield and yield attributing character were recorded after harvesting of the crop. Economics of each treatment was calculated on the basis of university sale rate (maize) and market price of inputs. The data of each character were pooled and analyzed as per procedure advocated by Gomez and Gomez, (1984).The quantity of nutrient required to achieve target yield was calculated by using the formulae for different technique is given Table 1.

The nutrient requirement to achieve target yield through Site-Specific Nutrient Management (SSNM) was calculated by using the formulae (Biradar and Aladakatti, 2007).

Where, $\mathrm{T}=$ Target yield $\left(\mathrm{t} \mathrm{ha}^{-1}\right)$

$\mathrm{EFR}=$ Effective fertilizer rate (if the soil nutrient supply status is low, medium and high applied 20 per cent higher, same and 20 per cent lower than the estimated required quantity of nutrients, respectively). 
The STCR equation developed by the All India Coordinated Research Project (AICRP) on Soil Test Crop Response (STCR), Bengaluru (Anon., 2007) was used in the study and is as follows:

$\mathrm{FN}=3.45 \mathrm{~T}-0.093 \mathrm{SN}\left(\mathrm{KMnO}_{4}-\mathrm{N}\right)$

$\mathrm{FP}_{2} \mathrm{O}_{5}=2.00 \mathrm{~T}-0.31 \mathrm{~S} \mathrm{P}_{2} \mathrm{O}_{5}\left(\right.$ Olsen's $\left.-\mathrm{P}_{2} \mathrm{O}_{5}\right)$

$\mathrm{FK}_{2} \mathrm{O}=1.04 \mathrm{~T}-0.046 \mathrm{~S} \mathrm{~K} \mathrm{~K}_{2} \mathrm{O}\left(\mathrm{NH}_{4} \mathrm{OAC}-\right.$ $\mathrm{K}_{2} \mathrm{O}$ )

Where,

$\mathrm{T}=$ Target yield $\left(\mathrm{t} \mathrm{ha}^{-1}\right)$

$\mathrm{FN}=$ Nitrogen supplied through fertilizer in $\mathrm{kg} \mathrm{ha}^{-1}$

$\mathrm{FP}_{2} \mathrm{O}_{5}=$ Phosphorus supplied through fertilizer in $\mathrm{kg} \mathrm{ha}^{-1}$

$\mathrm{FK}_{2} \mathrm{O}=$ Potassium supplied through fertilizer in $\mathrm{kg} \mathrm{ha}^{-1} \mathrm{~T}=$ Target yield

$\mathrm{S} \mathrm{N}, \mathrm{S} \mathrm{P}_{2} \mathrm{O}_{5}, \mathrm{~S} \mathrm{~K}_{2} \mathrm{O}=$ Initial soil test value for available $\mathrm{N}, \quad \mathrm{P}_{2} \mathrm{O}_{5}$ and $\mathrm{K}_{2} \mathrm{O} \quad\left(\mathrm{kg} \mathrm{ha}{ }^{-1}\right)$, respectively.

\section{Results and Discussion}

\section{Effect of maize hybrids}

Growth and yield attributes: The experimental data pertaining to growth and yield attributes of hybrid maize during kharif 2014, 2015 and 2016 are presented in Table 1. It showed that the Hybrid P3441 significantly influenced the tallest plant height $(175.9 \mathrm{~cm})$ as compared to hybrid Hishel $(163.7 \mathrm{~cm})$. Similarly, the higher days for tasseling (55.2), silking (58.6) and maturity (109.1) were observed in Hishel, whereas, lower days were recorded in $\mathrm{P} 3441$ (53.9 days, 56.9 days, 106.3 days), respectively. Likewise, the hybrid P3441 measured the bigger cob length
$(16.3 \mathrm{~cm})$, cob girth $(14.8 \mathrm{~cm})$, more no. of grain rows/ cob (12.5), no of grains/row (30.3) and found maximum thousand grain weight $(292.4 \mathrm{~g})$ than Hishel $(15.5 \mathrm{~cm}, 14.5$ $\mathrm{cm}, 11.1,29.7,283.3 \mathrm{~g}$ ), respectively. The difference between maize hybrids in relation to growth and yield attributes were also reported by Singh et al., (2006), Ramchandrappa et al., (2007) and Singh et al., (2014, 2016).

The high plant geometry $(50 \mathrm{~cm} \times 20 \mathrm{~cm})$ influenced taller plant height $(170.5 \mathrm{~cm})$ which remained at par with normal plant geometry $(60 \mathrm{~cm} x 20 \mathrm{~cm})$ i. e. $169.1 \mathrm{~cm}$. Similarly, higher days for tasseling (55.0), silking (58.1) and maturity (107. 8) were observed under high plant geometry $(50 \mathrm{cmx}$ $20 \mathrm{~cm})$ than normal plant geometry (60 cmx20 cm)i. e. 54.1 days, 57.4 days, 107.6 days, respectively. The high row spacing (50 cmx $20 \mathrm{~cm}$ ) measured the bigger cob length $(16.0 \mathrm{~cm})$, cob girth $(14.8 \mathrm{~cm})$, more grain rows/ cob (11.9), no of grains/row (30.1) and recorded maximum thousand grain weight (292.1 g) as compared to normal row spacing $(60 \mathrm{~cm}$ x20 cm)i. e. smaller cob length $(15.9$ $\mathrm{cm})$, cob girth $(14.6 \mathrm{~cm})$, less grain rows/ cob (11.7), no of grains/row (30. 0) and showed minimum thousand grain weight $(283.5 \mathrm{~g})$. This might be due to higher plant row $50 \mathrm{~cm}$ spacing as compared to normal plant row spacing $60 \mathrm{~cm}$. The plant geometry provides the opportunity for better growth and yield attributes. The findings are in conformity with the result of Sahoo and Chandrappa (2007) and Singh et al., (2014) and Singh et al., (2016).

The experimental result pertaining to nutrient management practice on growth and yield attributes of hybrid maize in Table 1 revealed that, Soil Test Crop Response (STCR) significantly influenced the tallest plant height $(173.2 \mathrm{~cm})$ with lower days for tasseling (54.8), higher days for silking (58.2) and 
maturity (108. 3) as compared to SSNM (168.9 cm, 54.9 days, 57.7days, 107.2 days) and RDF (67.2 cm, 54.1 days, 57.4 days and 107.6 days), respectively. Increase input efficiency improved $\mathrm{N}, \mathrm{P}, \mathrm{K}$ supplying capacity of soil resulting in higher plant height because nitrogen is needed for the formation of chlorophyll, phosphorus for the synthesis of nucleic acids and similarly potassium is important for the growth and elongation probably due to its function as an osmoticum and may react synergistically with indole acetic acid which is responsible for growth and development. Similarly, STCR practice significantly measured the longest cob length $(17.2 \mathrm{~cm})$, cob girth $(15.6 \mathrm{~cm})$, more no. of grain rows/ cob (12.6), no. of grains/row (30.9) which was significantly superior to SSNM $(16.1 \mathrm{~cm}, 14.5 \mathrm{~cm}, 11.8$, 30.7) and RDF (15.6 cm, $13.9 \mathrm{~cm}, 11.0,28.5)$, respectively. Likewise, STCR practice found maximum thousand grain weight $(291.6 \mathrm{~g})$ which was significantly superior over RDF (287.7 g) but, it remained at par with SSNM (289.8g). This might be due to higher plant row $50 \mathrm{~cm}$ spacing as compared to normal plant row spacing $60 \mathrm{~cm}$. The plant geometry provides the opportunity for better growth and yield attributes. The findings are in conformity with the result of Sahoo and Chandrappa (2007) and Singh et al., (2014) and Singh et al., (2016).

Yield: The perusal of data related to yield and economics of hybrid maize during kharif 2014, 2015 and 2016 are presented in Table 2. It showed that among the two hybrids, higher plant population 86.7 thousand/ha was recorded in Hishel while, lower plant population 86.4 thousand/ha was noted under P 3441. Similarly, hybrid P3441 significantly produced maximum cob yield $(7122 \mathrm{~kg} / \mathrm{ha})$, grain yield $(6202 \mathrm{~kg} / \mathrm{ha})$ and stover yield $(17791 \mathrm{~kg} / \mathrm{ha})$ which was $11.1 \%, 7.7 \%$, $14.4 \%, 18.0 \%, 15.6 \%$ higher over Hishel (6413 kg/ha, $5739 \mathrm{~kg} / \mathrm{ha}, 15550 \mathrm{~kg} / \mathrm{ha})$ respectively. Better vegetative and reproductive growth of maize hybrids contributed towards higher dry matter accumulation resulting in significantly higher grain and stover yield with maize hybrid $\mathrm{P}$ 3441.The variation in yield between the two hybrids might be due to genetic potential variation of the hybrid (Singh et al., 2014). Likewise, among the two plant geometry, the high plant geometry $(50 \mathrm{~cm} \times 20 \mathrm{~cm})$ significantly produced maximum cob yield (7497 kg/ha), grain yield (6122 kg/ha) and stover yield (17783 $\mathrm{kg} / \mathrm{ha})$ as compared to normal plant geometry $(60 \mathrm{~cm} 20 \mathrm{~cm})$ i.e. $6327 \mathrm{~kg} / \mathrm{ha}, 5684 \mathrm{~kg} / \mathrm{ha}$ and $15557 \mathrm{~kg} / \mathrm{ha}$, respectively. The increase in cob yield, grain yield and stover yield of high row spacing 50 $\mathrm{cm} \times 20 \mathrm{~cm}$ was $18.5 \%, 7.7 \%$ and $14.3 \%$ higher over normal row spacing $60 \mathrm{cmx} 20$ $\mathrm{cm}$. The higher grain and stover yield of maize was mainly due to better translocation of photosynthates from source to sink and higher growth attributing characters. The higher grain yield of P3441 could be mainly attributed to higher grain weight per cob over Hishel.

Similarly, among the three nutrient management practices, Soil Test Crop Response (STCR) significantly resulted in highest cob yield $(7564 \mathrm{~kg} / \mathrm{ha})$, grain yield (6328 kg/ha) and stover yield (17786 kg/ha) over RDF (6219 kg/ha, $5310 \mathrm{~kg} / \mathrm{ha}$ and 14792 $\mathrm{kg} / \mathrm{ha}$ ), but it remained at par with SSNM (7237 kg/ha, $6074 \mathrm{~kg} / \mathrm{ha}$ and $17228 \mathrm{~kg} / \mathrm{ha}$ ), respectively. The increase in cob yield, grain yield and stover yield of STCR was $21.6 \%$, $19.2 \%, 20.2 \%$ higher over RDF and $16.3 \%$, $14.4 \%$ and $16.5 \%$ as compared to SSNM, respectively. It indicates that the recommendation domain of maize owing to ever declining soil health specially for some of the macro nutrients, increasing level of nutrients probably exerted a positive effect on the development of source and sink strength of the plant which ultimately resulted in 
higher yield. These findings are in conformity with the findings of Parthipan et al., (2003), Sahoo et al., (2007), Singh et al., (2013) and Singh et al., (2016). Values of plant height and yield attributes were recorded under recommended dose of fertilizers which might be due to low availability of nutrients to the crop for development of height and yield attributes.

Table.1 Effect of planting density and nutrient management practices on growth and yield attributing characters of hybrid maize during kharif season (mean of three years)

\begin{tabular}{|c|c|c|c|c|c|c|c|c|c|}
\hline Treatment & $\begin{array}{l}\text { Plant } \\
\text { height } \\
\text { (cm) }\end{array}$ & $\begin{array}{l}\text { Days to } \\
\mathbf{5 0 \%} \\
\text { tasseling }\end{array}$ & $\begin{array}{l}\text { Days to } \\
50 \% \\
\text { silking }\end{array}$ & $\begin{array}{l}\text { Days to } \\
\text { maturity }\end{array}$ & $\begin{array}{l}1000 \\
\text { grain } \\
\text { weight }(\mathrm{g})\end{array}$ & $\begin{array}{l}\text { Cob } \\
\text { length } \\
\text { (cm) }\end{array}$ & $\begin{array}{l}\text { Cob } \\
\text { girth } \\
\text { (cm) }\end{array}$ & $\begin{array}{l}\text { No of } \\
\text { grain } \\
\text { rows/ } \\
\text { cob }\end{array}$ & $\begin{array}{l}\text { No. of } \\
\text { grains/row }\end{array}$ \\
\hline \multicolumn{10}{|l|}{ Hybrid } \\
\hline Hishel & 163.7 & 55.2 & 58.6 & 109.1 & 283.3 & 15.5 & 14.5 & 11.1 & 29.7 \\
\hline P 3441 & 175.9 & 53.9 & 56.9 & 106.3 & 292.4 & 16.3 & 14.8 & 12.5 & 30.3 \\
\hline $\mathrm{CD}(\mathbf{P}=\mathbf{0 . 0 5})$ & 7.8 & 1.0 & 0.5 & 1.8 & NS & NS & NS & 0.2 & NS \\
\hline \multicolumn{10}{|l|}{ Plant geometry } \\
\hline $60 \mathrm{~cm} \times 20 \mathrm{~cm}$ & 169.1 & 54.1 & 57.4 & 107.6 & 283.5 & 15.9 & 14.6 & 11.7 & 30.0 \\
\hline $50 \mathrm{~cm} \times 20 \mathrm{~cm}$ & 170.5 & 55.0 & 58.1 & 107.8 & 292.1 & 16.0 & 14.8 & 11.9 & 30.1 \\
\hline CD $(\mathbf{P}=\mathbf{0 . 0 5})$ & NS & NS & NS & NS & NS & NS & NS & NS & NS \\
\hline \multicolumn{10}{|l|}{$\mathrm{N}, \mathrm{P}$ and $\mathrm{K}\left(\mathrm{Kg} \mathrm{ha}^{-1}\right)$} \\
\hline RDF(120:60:60) & 167.2 & 54.1 & 57.4 & 107.6 & 287.7 & 15.6 & 13.9 & 11.0 & 28.5 \\
\hline STCR(143:15:78) & 173.2 & 54.8 & 58.2 & 108.3 & 291.6 & 17.2 & 15.6 & 12.6 & 30.9 \\
\hline SSNM (140:41:77) & 168.9 & 54.9 & 57.7 & 107.2 & 289.8 & 16.1 & 14.5 & 11.8 & 30.7 \\
\hline $\mathrm{CD}(\mathbf{P}=\mathbf{0 . 0 5})$ & 2.7 & NS & NS & 0.9 & 3.8 & 0.7 & 0.4 & 0.7 & 0.9 \\
\hline
\end{tabular}

Table.2 Effect of planting density and nutrient management practices on yield and economics of hybrid maize during kharif season (mean of three years)

\begin{tabular}{|l|c|c|c|c|c|c|}
\hline Treatment & $\begin{array}{c}\text { Plants/ha } \\
(\mathbf{( 1 0 0 0 )}\end{array}$ & $\begin{array}{c}\text { Cob yield } \\
(\mathbf{k g} / \mathbf{h a})\end{array}$ & $\begin{array}{c}\text { Grain yield } \\
(\mathbf{k g} / \mathbf{h a})\end{array}$ & $\begin{array}{c}\text { Stover yield } \\
(\mathbf{k g} / \mathbf{h a})\end{array}$ & Net return $(\mathbf{R s )}$ & B:C \\
\hline Hybrid & & & & & & \\
\hline Hishel & 86.7 & 6413 & 5680 & 15550 & 47041 & 1.22 \\
\hline P 3441 & 86.4 & $7122(11.1 \%)$ & $6127(7.9 \%)$ & $17791(14.4 \%)$ & $55488(18.0 \%)$ & 1.40 \\
\hline CD (P=0.05) & NS & 445.2 & 238.5 & 519.5 & 3413.0 & 0.10 \\
\hline Plant geometry & & & & & & \\
\hline 60cmx20cm & 88.2 & 6327 & 5684 & 15557 & 47161 & 1.34 \\
\hline $\mathbf{5 0 c m x 2 0 c m}$ & 94.4 & $7497(18.5 \%)$ & $6122(7.7 \%)$ & $17783(14.3 \%)$ & $55368(17.4 \%)$ & 1.41 \\
\hline CD (P=0.05) & 2.1 & 458.8 & 182.8 & 756.75 & 2440.9 & 0.06 \\
\hline N, P and K (Kg ha $\mathbf{- 1})$ & & & & & & \\
\hline RDF(120:60:60) & 87.4 & 6219 & 5310 & 14792 & 41741 & 1.11 \\
\hline STCR(143:15:78) & 85.9 & $7564(21.6 \%)$ & $6328(19.2 \%)$ & $17786(20.2 \%)$ & $57912(38.8 \%)$ & 1.46 \\
\hline SSNM (140:41:77) & 85.8 & $7237(16.3 \%)$ & $6074(14.4 \%)$ & $17228(16.5 \%)$ & $54141(29.7 \%)$ & 1.38 \\
\hline CD (P=0.05) & 1.4 & 314.7 & 231.2 & 551.65 & 3126.0 & 0.08 \\
\hline
\end{tabular}


Economics: The experimental data pertaining to economics of hybrid maize exhibited that hybrid P3441 influenced maximum net return of Rs.55488 which was $18.0 \%$ higher with $\mathrm{B}: \mathrm{C}$ ratio of 1.40 as compared to hybrid Hishel (Rs 47041, 1.22), respectively. Similarly, the high plant geometry $(50 \mathrm{~cm}$ x 20 $\mathrm{cm})$ significantly showed highest net return of Rs.55368 of $17.4 \%$ more with $\mathrm{B}: \mathrm{C}$ ratio of 1.41 over normal plant geometry $(60 \mathrm{~cm} \times 20$ $\mathrm{cm})$ i. e. net return of Rs. 47161 with $\mathrm{B}: \mathrm{C}$ ratio of 1.34. The difference in net income and B:C ratio might be due to yield variation between both the plant geometry. Similar findings were also reported by Singh et al., (2013 and 2016). Likewise, Soil Test Crop Response (STCR) practice significantly increased maximum net return of Rs.57921 with $38.8 \%$ higher with $\mathrm{B}: \mathrm{C}$ ratio of 1.46 over $\mathrm{RDF}$ (net return of Rs.41741 with B:C ratio of 1.11) and SSNM (net return of Rs.54141 with B:C ratio of 1.38).

On the basis of three years result, it may be concluded that cultivation of maize hybrids during Kharif season responded to high density planting $(50 \times 20) \mathrm{cm}^{2}$ with $7.7 \%$ higher yield over normal density (60 x 20) $\mathrm{cm}^{2}$. Among various nutrient management practices (RDF, STCR \& SSNM), STCR exhibited significantly superior (19.2\%) higher yield over RDF but, it was at par with SSNM. and RDF. STCR was found significantly superior with $19.2 \%$ higher yield over RDF. Hence, cultivation of maize hybrids with high plant geometry $(50 \mathrm{~cm} \times 20$ $\mathrm{cm}$ ) along with soil test crop response (STCR) management practice was found to be most effective and suitable technique for enhancing maize productivity at Odisha condition during Kharif season.

\section{References}

Gomez, K.A. and Gomez, A.A. (1984) Statistical procedures for agriculture research second edition. An International rice research institute book, A Wiely, inter science publication, John Wiely and Sons, New York.

ICAR-IIMR. 2016. Annual Report 2016-17, ICAR- Indian Institute of Maize Research, New Delhi, pp.3.

Parthipan, T. and PremSekhar, M. (2003) Response of hybrid maize to different levels and time of fertilization under irrigated condition. Journal of Agricultural Management 2(1\&2):4146.

Ramachandrappa, B. K., Nanjappa, H. V. and Soumya, T. M. (2007) Sensory parameters, nutrient contents, yield and yield attributes of baby corn varieties as influenced by stages of harvest. Mysore Journal of Agricultural Sciences, 41(1): 1-7.

Sahoo, S.C. and Mahapatra, P.K. (2007) Response of sweet corn (Zea mays L.) toplant population and fertility levels during rabi season. Indian Journal of Agricultural Sciences, 77:711-14.

Singh, D. and Singh, S.M. (2006). Response of early maturing maize (Zea mays) hybrids to applied nutrients and plant densities under agro-climatic conditions of Udaipur in Rajsthan. Indian Journal of Agronomy, 76: 372-374.

Singh, M. V. (2016) Effect of planting density and nutrient management on performance of Rabi hybrid maize. Annals of Plant and Soil Research 18(3):275-279.

Singh, M. V., Kumar, N. Singh, B. and Prakash, V. (2016) Productivity and profitability of rabi maize hybrids under nutrient management practices. Annals of Plantand Soil Research 18(1):70-73.

Singh, M.V., Kumar, N. and Mishra, B.N. (2013) Integrated use of nitrogen and FYM on yield, nutrient uptake and economics of maize in eastern Uttar 
Pradesh. Annals of Plant and Soil Research 15(2):128-130.

Singh, M.V., Prakash, V., Singh, B. and Shahi, H. N. (2014) Response of maize hybrids to integrated nutrient management. Haryana Journal of Agronomy 30(1): 65-69.

\section{How to cite this article:}

Pramila Naik, Ashutosh Nanda, Digvijay Swain, Kalpataru Nanda and Rutuparna Paikaray. 2021. Effect of Planting Density and Nutrient Management Practices on the Performance of Maize Hybrids during kharif Season. Int.J.Curr.Microbiol.App.Sci. 10(02): 577-584. doi: https://doi.org/10.20546/ijcmas.2021.1002.068 